\title{
Measurement by ICP-MS of lead in plasma and whole blood of lead workers and controls
}

\author{
Andrejs Schütz, Ingvar A Bergdahl, Anders Ekholm, Staffan Skerfving
}

\begin{abstract}
Objectives-To test a simple procedure for preparing samples for measurement of lead in blood plasma (P-Pb) and whole blood (B-Pb) by inductively coupled plasma mass spectrometry (ICP-MS), to measure $\mathbf{P}-\mathbf{P b}$ and $\mathrm{B}-\mathrm{Pb}$ in lead workers and controls, and to evaluate any differences in the relation between $\mathrm{B}-\mathrm{Pb}$ and $\mathrm{P}$ $\mathrm{Pb}$ between people.

Methods-P-Pb and $\mathrm{B}-\mathrm{Pb}$ were measured by ICP-MS in 43 male lead smelter workers and seven controls without occupational exposure to lead. For analysis, plasma and whole blood were diluted 1 in 4 and 1 in 9, respectively, with a diluted ammonia solution containing Triton-X 100 and EDTA. The samples were handled under routine laboratory conditions, without clean room facilities.

Results-P-Pb was measured with good precision ( $\mathrm{CV}=5 \%)$ even at concentrations present in the controls. Freeze storage of the samples had no effect on the results. The detection limit was $0.015 \mu \mathrm{g} / 1$. The $\mathbf{P}-\mathrm{Pb}$ was 0.15 (range $0.1-0.3$ ) $\mu \mathrm{g} / 1$ in controls and $1.2(0.3-3.6) \mu \mathrm{g} / 1$ in lead workers, although the corresponding BPbs were 40 (24-59) $\mu g / 1$ and 281 (60-530) $\mu \mathrm{g} / 1$ (1 $\mu \mathrm{g} \mathrm{Pb} / \mathrm{l}=4.8 \mathrm{nmol} / \mathrm{l})$. $\mathrm{B}-\mathrm{Pb}$ was closely associated with $\mathrm{P}-\mathrm{Pb}(\mathbf{r}=0.90)$. The association was evidently non-linear; the ratio $\mathrm{B}-\mathbf{P b} / \mathbf{P}-\mathbf{P b}$ decreased with increasing $\mathbf{P}-\mathbf{P b}$.

Conclusions-By means of ICP-MS and a simple dilution procedure, $\mathrm{P}-\mathrm{Pb}$ may be measured accurately and with good precision down to concentrations present in controls. Contamination of blood at sampling and analysis is no major problem. With increasing $\mathbf{P}-\mathrm{Pb}$, the percentage of lead in plasma increases. In studies of lead toxicity, P-Pb should be considered as a complement to current indicators of lead exposure and risk.
\end{abstract}

(Occup Environ Med 1996;53:736-740)

Keywords: lead; plasma; ICP-MS

Lead is a common pollutant of the general environment and many workplaces. Exposure to lead occurs through inhalation of particles containing lead and ingestion of food, drinking water, settled indoor dust, and soil contaminated with lead. Lead is absorbed through the lungs or the gastrointestinal tract into the blood.

After entering the plasma most (about 99\%) of the lead is taken up into the erythrocytes. ${ }^{1}$ In vitro experiments indicate a very rapid equilibration of lead between plasma and erythrocytes (within minutes). ${ }^{1-5}$ Most of the lead remaining in the plasma $(\mathrm{P}-\mathrm{Pb})$ may be bound to albumin. ${ }^{67}$

Studies of $\mathrm{P}-\mathrm{Pb}$ or serum lead $(\mathrm{S}-\mathrm{Pb})$ have given varying results; values between $0.02^{8}$ and $550 \mu \mathrm{g} / 1^{9}$ have been reported for single subjects without occupational exposure to lead. When considering only results obtained by analytical techniques capable of reaching adequate detection limits-such as electrothermal atomisation atomic absorption spectrometry (ETA-AAS) and mass spectrometry (MS) the variation still ranges over one to two orders of magnitude in people without any occupational exposure.

Most studies did not show any association between $\mathrm{B}-\mathrm{Pb}$ and $\mathrm{P}-\mathrm{Pb},{ }^{10-13}$ although some studies showed a significant correlation. ${ }^{1}{ }^{14} 15$ Furthermore, two of the studies clearly indicated a curvilinear relation between $\mathrm{B}-\mathrm{Pb}$ and $\mathrm{P}$-Pb. ${ }^{1}{ }^{15}$ Interestingly, similar non-linear relations with $\mathrm{B}-\mathrm{Pb}$ have also been found for lead uptake, ${ }^{16-22}$ urinary lead excretion, ${ }^{23}$ various biological indicators, ${ }^{13}{ }^{23-29}$ and health effects. ${ }^{30}{ }^{33}$ Accordingly, it can be hypothesised that some of these exponential associations will become rectilinear when $\mathrm{B}-\mathrm{Pb}$ is exchanged for $\mathrm{P}-\mathrm{Pb}$.

Thus $\mathrm{P}-\mathrm{Pb}$ may be a more relevant index than $\mathrm{B}-\mathrm{Pb}$ of exposure, distribution, and health risks. Also from a physiological point of view, it is reasonable to assume that toxic effects of lead are primarily associated with P$\mathrm{Pb}$, which should reflect the most rapidly exchangeable fraction of lead in the bloodstream. Despite this, no attempts seem to have been made to introduce $\mathrm{P}-\mathrm{Pb}$ in the monitoring of lead uptake and health risks. Analytical problems at the low concentrations found are major reasons why $\mathrm{P}-\mathrm{Pb}$ has not been used. However, the development of analytical techniques has proceeded, and especially MS in combination with inductively coupled plasma (ICP-MS) has developed into a very powerful technique for the measurement of trace elements in samples such as biological fluids.

The aims of the present study were to test a simple procedure for preparation of samples combined with ICP-MS to measure $\mathrm{P}-\mathrm{Pb}$, to evaluate the effect of freeze storage on $\mathrm{P}-\mathrm{Pb}$ results, to study the $\mathrm{P}-\mathrm{Pb}$ in groups of lead workers and controls, to investigate the rela- 
tion between $\mathrm{B}-\mathrm{Pb}$ and $\mathrm{P}-\mathrm{Pb}$ at varying values of $\mathrm{P}-\mathrm{Pb}$, and to evaluate variation between people.

\section{Materials and methods}

At a secondary lead smelter in southern Sweden, 43 male workers and seven male hospital laboratory staff were studied. On the day of sampling, the lead workers were on duty at the smelter. Before blood sampling, they had a shower and changed into clean clothes. The samples from the lead workers were obtained at the healthcare centre at the plant in connection with regular blood sampling for $\mathrm{B}-\mathrm{Pb}$ monitoring. The median (range) age was 35 (20-63) for the lead workers and $41(35-59)$ for the controls.

Venous blood was drawn from the cubital vein into an evacuated, heparinised $10 \mathrm{ml}$ Venoject (Terumo Europe NV, Leuven, Belgium) tube. A set of the sampling tubes had been checked for lead contamination by leaching with $10 \mathrm{ml} 1 \%$ nitric acid for 16 hours. A mean (range) lead content of 1.0 $(0.3-1.9)$ ng per tube $(n=10)$ was obtained, corresponding to $0 \cdot 10(0.03-0.19) \mu \mathrm{g} / 1$ whole blood. Plasma was separated by centrifugation (15 minutes, $1500 \mathrm{~g}$ ) and transferred by acid washed Pasteur pipettes into acid washed, screw capped polypropylene tubes. In 9 of the samples from the lead workers, a "slight" or "obvious" haemolysis was recorded on the sample protocol. The samples were analysed fresh. Forty plasma samples were reanalysed after three months' storage in a freezer $\left(-20^{\circ} \mathrm{C}\right)$. Before analysis of the frozen samples, they were thawed, treated in an ultrasonic bath for $60 \mathrm{~s}$, and centrifuged (10 minutes, $200 \mathrm{~g}$ ). The clear supernatant fluid was used for analysis.

\section{CONTROL SAMPLES}

A commercial reference sample of lyophilised serum, without any data on lead concentration (seronorm trace elements, batch 010017, Nycomed AS, Oslo), and two samples of whole blood, with recommended lead concentrations (seronorm, batches 205052 and 203056), were included in all analytical series.

\section{SAMPLE PREPARATION}

Blood plasma $(1.00 \mathrm{ml})$ was transferred into acid washed, screw capped polypropylene tubes and diluted with $4.0 \mathrm{ml}$ deionised Millipore water containing ammonia (0.04 $\mathrm{M})$, Triton-X $100(100 \mathrm{mg} / \mathrm{l})$, and disodium ethylenediaminetetra-acetate dihydrate $\left(\mathrm{Na}_{2}-\right.$ EDTA; $200 \mathrm{mg} / \mathrm{l})$. A similar sample preparation was used by Lutz et al for whole blood analysis by ICP-MS. ${ }^{34}$ Bismuth nitrate $(25 \mathrm{ng}$ ${ }^{209} \mathrm{Bi}$ in $100 \mu \mathrm{l}$ ) was added to each sample as an internal standard to compensate for fluctuations in instrument stability. The normal concentration of $\mathrm{Bi}$ in human plasma has been reported to be very low $(<0 \cdot 25 \mathrm{ng} / \mathrm{ml}),{ }^{35}$ which is in accordance with pilot studies performed at our laboratory. Thus an interference with the internal standard is very unlikely.

Whole blood was homogenised by $10 \mathrm{~min}$ - utes of mechanical shaking, then $0.50 \mathrm{ml}$ aliquots were diluted with $4.5 \mathrm{ml}$ deionised water containing ammonia $(0.07 \mathrm{M})$, Triton$\mathrm{X} 100(500 \mathrm{mg} / \mathrm{l})$, and $\mathrm{Na}_{2}$-EDTA (500 mg/l); $50 \mathrm{ng}{ }^{209} \mathrm{Bi}$ was added to the whole blood samples.

\section{MEASUREMENT OF LEAD}

Lead was measured by ICP-MS (PlasmaQuad $2+$, Fisons Instruments, Winsford, UK). The samples were introduced with a segmented flow technique $(1.0 \mathrm{ml} / \mathrm{min} ; 10 \mathrm{~s}$ for plasma and $14 \mathrm{~s}$ for whole blood) through a Meinhard nebuliser and a chilled spray chamber. No flow injection valve was used; the autosampler was simply programmed to stay in the sampling position for the specified time. The argon plasma conditions were: forward power $1350 \mathrm{~W}$; reflected power $<5 \mathrm{~W}$; nebuliser gas flow rate $0 \cdot 9$, intermediate and outer gas flow rates 0.8 and $13.0 \mathrm{l} / \mathrm{min}$, respectively. Interface cones of nickel were used. The instrument was run in peak jumping mode, with ${ }^{206} \mathrm{~Pb},{ }^{207} \mathrm{~Pb},{ }^{208} \mathrm{~Pb}$, and ${ }^{209} \mathrm{Bi}$ monitored at three points per peak. The sum of the three lead isotopes was used for calculations. For plasma analysis, the dwell time was $70 \mathrm{~ms} /$ point for lead and $20 \mathrm{~ms} /$ point for $\mathrm{Bi}$, and the acquisition time was eight seconds. For whole blood analysis, the dwell time was $15 \mathrm{~ms} /$ point for lead and $10 \mathrm{~ms} /$ point for $\mathrm{Bi}$, and the acquisition time was 20 seconds. The instrument was calibrated against spiked plasma ( +5 and $+10 \mu \mathrm{g} / \mathrm{l}$ ) and whole blood $(+100$ and $+500 \mu \mathrm{g} / 1)$ samples.

All samples were analysed in duplicate. The entire sample handling and analysis was carried out in a laboratory designed for routine measurements of trace elements, but without clean room facilities.

The instrument capacity was about $50 \mathrm{P}-\mathrm{Pb}$ measurements an hour. Thus, despite a high initial instrument cost, the measurement of $\mathrm{P}$ $\mathrm{Pb}$ is not expensive when the samples are run in a large series.

\section{Results}

In samples without haemolysis the median (range) $\mathrm{P}-\mathrm{Pb}$ was $1 \cdot 2(0 \cdot 23-3 \cdot 6) \mu \mathrm{g} / \mathrm{l}(\mathrm{n}=34)$ in lead workers and $0 \cdot 15(0 \cdot 10-0 \cdot 17) \mu \mathrm{g} / 1$ in controls. The corresponding $\mathrm{B}-\mathrm{Pbs}$ were 281 $(60-531)$ and $40(24-59) \mu \mathrm{g} / \mathrm{l}$.

There was a very close association $(r=$ $0.90, P<0.001$; haemolysed samples not included) between $\mathrm{B}-\mathrm{Pb}$ and $\mathrm{P}-\mathrm{Pb}$ (fig $1 \mathrm{~A}$ ). The data indicate a non-linear association between the variables. Logarithmic conversion of $\mathrm{P}-\mathrm{Pb}$ (with haemolysed samples excluded) gave a roughly rectilinear relation (fig $1 \mathrm{~B} ; r=$ 0.96). Samples with a notation of slight haemolysis did not differ in $\mathrm{P}-\mathrm{Pb}$ from the non-haemolysed ones. However, those with obvious haemolysis had slightly higher concentrations (fig 1A).

The table shows the results for the control samples. Our results for the whole blood samples are in good agreement with the recommended values.

The method precision, calculated as the 
Figure 1 Relation

between lead

concentrations in plasma

$(P-P b)$ and in whole blood

(B-Pb) in 43 secondary

lead smelter workers and

seven controls. Open circles

= samples without visible

haemolysis; filled circles $=$

slight haemolysis; crosses $=$

obvious haemolysis. (A)

Linear scale. (B)

Logarithmic scale;

rectilinear regression line:

$\log \mathrm{P}-\mathrm{Pb}=0.00277 \times \mathrm{B}-$

$\mathrm{Pb}-0.77$ ( $r=0.96$;

haemolysed samples

excluded). Considering the

metabolism of lead, it

seems logical to choose $P$

$\mathrm{Pb}$ as the independent

variable ( $x$ axis), although

other authors have chosen

$\mathrm{B}-\mathrm{Pb}$ as independent.

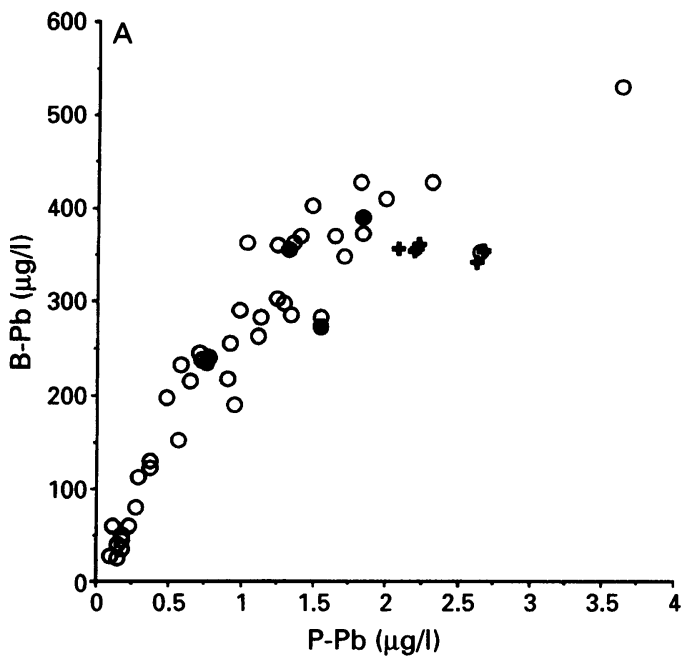

Lead concentration $(\mu \mathrm{g} / \mathrm{l})$ in lyophilised seronorm trace element control samples from Nycomed AS, Oslo, Norway

\begin{tabular}{lccl}
\hline Sample & $n$ & $\begin{array}{l}\text { Obtained } \\
\text { mean (range) }\end{array}$ & $\begin{array}{l}\text { Recommended } \\
\text { mean (range) }\end{array}$ \\
\hline $\begin{array}{l}\text { Serum, batch: } \\
\text { 010017 }\end{array}$ & 8 & $2 \cdot 5(2 \cdot 2-2 \cdot 8)$ & - \\
$\begin{array}{l}\text { Blood, batch: } \\
205052\end{array}$ & 10 & $31 \cdot 8(30 \cdot 1-32 \cdot 7)$ & $35(31-41)$ \\
203056 & 10 & $385(372-397)$ & $383(361-396)$ \\
\hline
\end{tabular}

$\mathrm{n}=$ Number of measurements.

Figure 2 Relation between lead concentrations in plasma $(P-P b)$, as measured in samples both fresh and after deep frozen storage for three months. The linear regression line is shown $(y=1.003 x$ $+0.007 ; r=0.995)$.

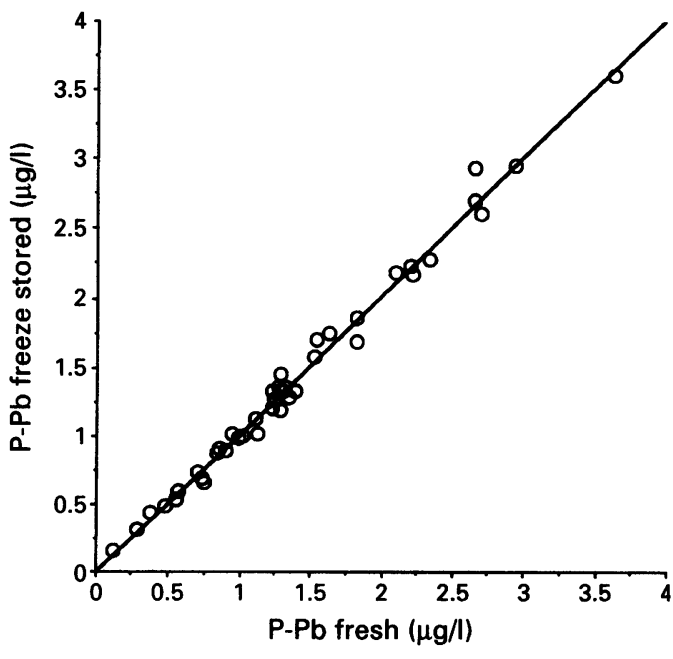

coefficient of variation from duplicate measurements, was $5 \cdot 1 \%$ for fresh plasma, $1 \cdot 3 \%$ for frozen plasma, and $1.8 \%$ for whole blood. The detection limit, calculated as three times the SD of repeated measurements $(n=10)$ of a reagent blanks, varied from day to day between $0.012 \mathrm{ng} / 1$ and $0.015 \mathrm{ng} / \mathrm{l}$.

A very close association was found between the results for frozen and fresh plasma samples, without any systematic differences (fig 2).

\section{Discussion}

The present study shows that it is now possible to measure $\mathrm{P}-\mathrm{Pb}$ with ICP-MS under routine laboratory conditions with good precision and a detection limit of about a 10th of the concentration among controls without occupational exposure to lead. A good precision in the measurements is verified by the close asso-

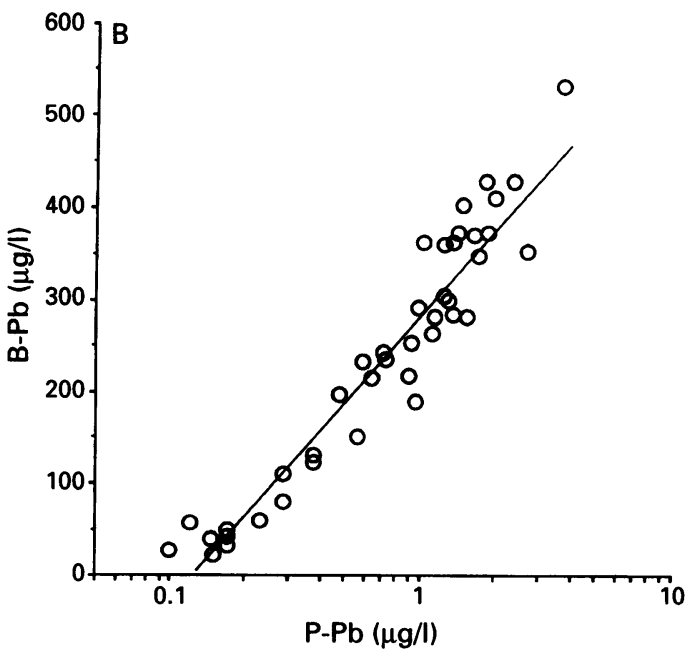

ciation between $\mathrm{B}-\mathrm{Pb}$ and $\mathrm{P}-\mathrm{Pb}$, as well as between $\mathrm{P}-\mathrm{Pb}$ in fresh and frozen samples. Also, the samples can be stored frozen without any effect on the results.

As there are no certified quality assurance samples for lead in plasma, the accuracy of the method for $\mathrm{P}-\mathrm{Pb}$ could not be verified with certainty. It is possible that the values are slightly too high due to the fact that no correction was made for contamination of the blood sampling tubes. However, taking into consideration the very rapid absorption of lead by erythrocytes, ${ }^{13-5}$ such a correction is not likely to be necessary.

The $\mathrm{P}-\mathrm{Pb}$ values in the present study are considerably lower than those reported in studies with atomic absorption spectroscopy techniques. Moreover, they are, together with the data reported by Everson and Patterson, ${ }^{8}$ the lowest values obtained in studies involving MS techniques. Accordingly, the present ratio $\mathrm{B}-\mathrm{Pb} / \mathrm{P}-\mathrm{Pb}$ is higher than most earlier results.

Most of the data on $\mathrm{P}-\mathrm{Pb}$ hitherto reported have been obtained by ETA-AAS techniques. However, in studies with ETA-AAS without any enrichment step, the detection limits, if reported, were $\geqslant 5 \mu \mathrm{g} / 1$ and no associations between $\mathrm{B}-\mathrm{Pb}$ and $\mathrm{P}-\mathrm{Pb}$ were found. ${ }^{10}{ }^{13} 36-39$ To increase the sensitivity and minimise the non-specific absorption from the sample matrix components at atomisation, ETA-AAS detection has been combined with a liquid/liquid extraction step. ${ }^{12} 1415$ The detection limits in these studies were reported to be $0.5 \mu \mathrm{g} / 1-$ $2 \mu \mathrm{g} / \mathrm{l}$, and the average $\mathrm{P}-\mathrm{Pb} / \mathrm{B}-\mathrm{Pb}$ ratio $1 \%-3 \%$, within a $\mathrm{B}-\mathrm{Pb}$ range up to about $1000 \mu \mathrm{g} / 1$. To obtain the highest instrumental sensitivity, the lead resonance line of $217 \mathrm{~nm}$ has been used in these studies. However, at this wavelength, the non-specific background absorption is substantial, and was certainly difficult to compensate for with older ETAAAS apparatus. This has, most probably, made these results less reliable.

In previous studies of $\mathrm{P}-\mathrm{Pb}$ with $\mathrm{MS}$ techniques, the number of people was generally very small; sometimes only one or two subjects. Only two of the studies give clear information on detection limits: $0.05 \mu \mathrm{g} / \mathrm{l}$, obtained by ICP-MS, ${ }^{35}$ and $0.001 \mu \mathrm{g} / 1$, combining elec- 
trothermal with isotope dilution ICP-MS. ${ }^{40}$ Everson and Patterson ${ }^{8}$ reported the $\mathrm{P}-\mathrm{Pb}$ for one control person and a lead worker to be $0.02 \mu \mathrm{g} / 1$ and $2 \mu \mathrm{g} / \mathrm{l}$, respectively, the ratios for $\mathrm{P}-\mathrm{Pb} / \mathrm{B}-\mathrm{Pb}$ were $0.02 \%$ and $0.25 \%$. Possibly, the $\mathrm{P}-\mathrm{Pbs}$ were too low due to overestimation of the effect of heparin blanks. Manton and Malloy described a decreasing $\mathrm{S}-\mathrm{Pb} / \mathrm{B}-\mathrm{Pb}{ }^{41}$ from $1.6 \%$ to $0.3 \%$ in a lead worker whose B$\mathrm{Pb}$ fell from $1160 \mu \mathrm{g} / 1$ to $310 \mu \mathrm{g} / \mathrm{l}$. A median (range) $\mathrm{S}-\mathrm{Pb}$ of $0.5(0.2-1.2) \mu \mathrm{g} / 1$ in six controls was reported by Manton and Cook. ${ }^{1}$

The relatively higher $\mathrm{P}-\mathrm{Pbs}$ reported in most earlier studies may also have explanations other than analytical problems-for example, extensive haemolysis at sampling or during storage before the separation of plasma, and contamination at sampling or sample preparation. However, the present data show that slight haemolysis gives no significant increase in $\mathrm{P}-\mathrm{Pb}$, and even obvious haemolysis only has a limited effect. Thus haemolysis can scarcely explain all the difference in the published data. Further, contamination of the samples before separation of plasma would, most probably, hardly influence the $\mathrm{P}-\mathrm{Pb},{ }^{1}$ as traces of inorganic lead would rapidly be absorbed by the erythrocytes. ${ }^{1-542}$ The use of the very strong chelator EDTA as an anticoagulant may, however, ${ }^{14}$ give falsely high P-Pbs due to extraction of lead from the erythrocytes. ${ }^{1415}$ Data from experiments with radiolabelled lead show that heparin does not extract lead from erythrocytes, ${ }^{4}$ although such an effect has been suggested by some authors. ${ }^{7}$

The association between $\mathrm{B}-\mathrm{Pb}$ and $\mathrm{P}-\mathrm{Pb}$ obtained in this study is much closer than reported in any other study. Moreover, this is the first study in which an association has been shown in the $\mathrm{B}-\mathrm{Pb}$ range most relevant for exposures of today in western countries $(<600$ $\mu \mathrm{g} / \mathrm{l})$. Possibly, the association would have been even closer if the B-Pbs had been corrected for differences in packed cell volume.

It has been suggested that the large scattering in the data of DeSilva ${ }^{15}$ and Manton and Cook $^{1}$ were caused by a short term effect on P$\mathrm{Pb}$ by ongoing absorption of inhaled or ingested lead. However, in the present study, the workers were exposed shortly before blood sampling, and they certainly had varying loads of particles containing lead in their lungs. Further, the controls were sampled at varying times relative to the intake of meals. The close association between $\mathrm{B}-\mathrm{Pb}$ and $\mathrm{P}-\mathrm{Pb}$ obtained thus contradicts the explanations by these authors.

Although the present study indicates that the variation between people in the distribution of lead between erythrocytes and plasma is limited, it may still be of toxicological relevance. Moreover, the maximum $\mathrm{B}-\mathrm{Pb}$ in our study was only $530 \mu \mathrm{g} / \mathrm{l}$, and none of the subjects had any symptoms or signs of intoxication. Accordingly, the considerable variation reported between symptoms and signs and B$\mathrm{Pb}^{30-33}$ may be caused by exceptional differences between people in the distribution of lead between erythrocytes and plasma. In such instances, $\mathrm{B}-\mathrm{Pb}$ has only limited value as an indicator of health risks.

The association between $\mathrm{B}-\mathrm{Pb}$ and $\mathrm{P}-\mathrm{Pb}$ was evidently non-linear; the ratio $\mathrm{B}-\mathrm{Pb} / \mathrm{P}-\mathrm{Pb}$ decreased with rising $\mathrm{P}-\mathrm{Pb}$. This agrees with some previous studies. ${ }^{1541}$ A possible explanation of the increasing fraction of lead in plasma with increasing $\mathrm{B}-\mathrm{Pb}$ may be a gradual saturation of the binding sites in erythrocytes with highest affinities to lead. For example the enzyme $\delta$-aminolevulinic acid dehydratase (ALAD) has been shown to bind lead ${ }^{434}$; the activity of ALAD is known to decrease immediately after a moderate increase in $\mathrm{B}-\mathrm{Pb} .^{23}$ Other explanations may be that haemolysis caused by lead results in release of lead that may be bound to a protein, ${ }^{6}$ or that lead induces an increase of protein that binds lead in plasma. The presence of such a protein has been indicated in erythrocytes of lead workers with B-Pbs $>1.9 \mu \mathrm{mol} / 1(400 \mu \mathrm{g} / \mathrm{l}){ }^{45}{ }^{46}$

The present study shows that P-Pb can be measured routinely and precisely by ICP-MS without advanced clean room facilities. Although the association found between $\mathrm{B}-\mathrm{Pb}$ and $\mathrm{P}-\mathrm{Pb}$ is very close, it may include a variation in $\mathrm{P}-\mathrm{Pb}$ large enough to be of toxicological significance. This should be considered as a possible explanation of differences in susceptibility to toxic effects of lead. It is thus time to generate data on the relation between $\mathrm{P}-\mathrm{Pb}$ and lead uptake and effects.

We thank Peter Planitz, formerly at Fisons Instruments Vertriebs-GmbH, for valuable methodological help in the initial steps of this work. Financial support was given by the tial steps of this work. Financial support was given by the Planning and Coordination of Research, the National Swedish Environment Protection Agency, and the Medical Faculty at Environment Protec
Lund University.

1 Manton WI, Cook JD. High accuracy (stable isotope dilution) measurements of lead in serum and cerebrospinal fluid. $\mathrm{Br}$ F Ind Med 1984;41:313 9.

2 Clarkson TW, Kench JE. Uptake of lead by human erythrocytes in vitro. Biochemistry 1958;69:432-9.

3 Campbell BC, Meredith PA, Moore MA, Watson WS. Kinetics of lead following intravenous administration in man. Toxicol Lett 1984;21:231-5.

4 Barton JC. Retention of radiolead by human erythrocytes in vitro. Toxicol Appl Pharmacol 1989;99:314-22.

5 Simons T. Lead transport and binding by human erythrocytes in vitro. Pflugers Arch 1993;423:307-13.

6 Moore MR. Haematological effects of lead. Sci Total Environ 1988;71:419-31.

7 Al-Modhefer AJA, Bradbury MWB, Simons TJB Observations on the chemical nature of lead in human blood serum. Clin Sci 1991;81:823-9.

8 Everson J, Patterson CC. "Ultra-clean" isotope dilution mass spectrometric analyses for lead in human blood plasma indicate that most reported values are artificially high. Clin Chem 1980;26:1603-7.

9 Copeland TR, Christie JH, Osteryoung RA, Skogerboe RK. Analytical applications of pulsed voltammetric stripping at thin film mercury electrodes. Anal Chem 1973; ping at thin

10 Rosen JF, Zarate-Salvador C, Trinidad EE. Plasma lead levels in lead-intoxicated children. $f$ Pediatr 1974;84: 45-8.

11 Baloh RW, Spivey GH, Brown CP, Morgan D, Campion DS, Browdy BL, et al. Subclinical effects of chronic increased lead absorption-a prospective study. $\mathcal{F}$ Occup Med 1979;21:490-6.

12 Araki S, Aono H, Murata K. Mobilization of heavy metals into the urine by Ca- EDTA: relation to erythrocyte and plasma concentrations and exposure indicators. $\mathrm{Br} \mathcal{F}$ Ind Med 1986;43:636-41.

13 Ong CN, Phoon WO, Lee BL, Lim LE, Chua LH. Lead in plasma and its relationships to other biological indicators. Ann Occup Hyg 1986;30:219-28.

14 Cavalleri A, Minoia C, Pozzoli L, Baruffini A Determination of plasma lead levels in normal subjects and in lead-exposed workers. $\mathrm{Br} \mathcal{F}$ Ind Med 1978.35. and in

15 Desilva PE. Determination of lead in plasma and studies on its relationship to lead in erythrocytes. $\mathrm{Br} F$ Ind Med its relationship

16 Williams MK, King E, Walford J. An investigation of lead 
absorption in an electric accumulator factory with use of personal samplers. Br f Ind Med 1969;26:202-16.

17 Azar A, Snee RD, Habibi K. Lead. An epidemiologica approach to community air lead exposure using personal air samples. Environmental Quality and Safety 1975 (suppl II):152-96

18 Chamberlain AC. Effect of airborne lead on blood lead Atmospheric Environment 1983;17:677-92.

19 UK Royal Commission on Environmental Pollution. Lead in the environment. Her Majesty's Stationery Office, London, 1983:176. (9th report No 8852.)

20 Brunekreef $B$. The relationship between air lead and blood lead in children. Sci Tot Environ 1984;38:79-123.

21 Laxen DPH, Raab GM, Fulton M. Children's blood lead and exposure to lead in household dust and water-a basis for an environmental standard for lead in dust. $S_{c i}$ Total Environ 1987;66:235-44.

22 Hodgkins DG, Hinkamp DL, Robins TG, Levine SP Schork MA, Krebs WH. Air-lead particle sizes in battery Schork MA, Krebs WH. Air-lead particle sizes in battery
manufacturing: potential effects on the OSHA complimanufacturing: potential effects on the OSHA compli

23 Schütz A, Skerfving S. Effect of a short, heavy exposure to lead dust upon lead level, erythrocyte $\delta$-aminolevulinic acid dehydratase activity and urinary excretion of lead, $\delta$ aminolevulinic acid, and coproporphyrine. Scand $\mathcal{f}$ Work Environ Health 1976;3:176-84.

24 Piomelli S. A micromethod for free erythrocyte porphyrines: the FEP test 7 Lab Clin Med 1973;81:932-40.

25 Tola S, Hernberg S, Asp S, Nikkanen J. Parameters indicative of absorption and biological effect in new lead indicative of absorption and biological effect in new lead 30:134-41

26 Baloh RW. Laboratory diagnosis of increased lead absorp-

27 Allesio L, Bertazzi PA, Monelli O, Foa V. Free erythrocyte protoporphyrin as an indicator of the biological effect of lead in adult males. Int Arch Occup Environ Health 1976; 37:89-105.

28 Joselow MM, Flores J. Application of the zinc protoporphyrin (ZP) test as a monitor of occupational exposure to lead. Am Ind Hyg Assoc f 1977;38:63-6.

29 Haeger-Aronsen B, Schütz A. Zink protoporphyrin in blood -a new method for assessment of the influence of lead. Läkartidningen 1978;75:3427-30.

30 Chamberlain MJ, Massey PMO Mild lead poisoning with an excessively high blood lead. Br 7 Ind Med 1972; an excessively

31 Torkington P, Bhalla KK. Lead poisoning with low blood lead levels. Postgrad Med f 1974;50:240-2.

32 Lilis R, Fischbein A, Eisinger J, Blumberg WE, Diamond $\mathrm{S}$, Anderson HA, et al. Prevalence of lead disease amon secondary lead smelter workers and biological indicators of lead exposure. Environ Res 1977;14:255-85.

33 Lilis R, Valciukas J, Fischbein A, Andrews G, Selikoff IJ, Blumberg W. Renal function impairment in secondary lead smelter workers: correlations with zinc protoporphyrin and blood lead levels. F Environ Pathol Toxicol 1979;2:1447-74.

34 Lutz TM, Nirel PMV, Schmidt B. Whole blood analysis by ICP-MS. In: Holland G, Eaton AN, eds. Applications of plasma source mass spectrometry. Cambridge, UK: The Royal Society of Chemistry, 1991:96-100.

35 Mauras Y, Premel-Cabic A, Berre S, Allain P. Simultaneous determination of lead, bismuth, and thallium in plasma and urine by inductively coupled plasma mass spectrometry. Clin Chim Acta 1993;218:201-5.

36 Conradi S, Ronnevi LO, Vesterberg O. Increased plasma levels of lead in patients with amyotrophic lateral sclerosis compared with control subjects as determined by flameless atomic absorption spectrophotometry. 7 Neurol Neurosurg Psychiatry 1978;41:389-93.

37 Conradi S, Ronnevi LO, Nise G, Vesterberg O. Long-time penicillamine-treatment in amyotrophic lateral sclerosis penicillamine-treatment in amyotrophic lateral sclerosis
with parallel determination of lead in blood, plasma, and urine. Acta Neurol Scand 1982;65:203-11.

38 Ronnevi LO, Conradi S, Nise G. Further studies on the uptake of lead in vitro in amyotrophic lateral sclerosis (ALS) patients and controls. F Neurol Sci 1982;57: 143-56.

39 Ishihara N, Shiojima S, Hasegawa K. Lead and zinc concentrations in plasma, erythrocytes, and urine in relation to ALA-D activity after intravenous infusion of $\mathrm{Ca}$ EDTA. Br ₹ Ind Med 1984;41:235-40.

40 Bowins RJ, McNutt RH. Electrothermal isotope dilution inductively coupled plasma mass spectrometry method inductively coupled plasma mass spectrometry method human plasma. Fournal of Analytical Atomic Spectrometry human plasma.

41 Manton WI, Malloy CR. Distribution of lead in body fluids after ingestion of soft solder. Br F Ind Med 1983;40:51-7.

42 Hursh JB, Suomela J. Absorption of $212 \mathrm{~Pb}$ from the gastrointestinal tract of man. Acta Radiologica Therapy Physics Biology 1968;7:108-20.

43 Sakai T, Yanagihara S, Kunugi Y, Ushio K. Relationship between distribution of lead in erythrocytes in vivo and in vitro and inhibition of ALA-D. Br F Ind Med 1982;39. 382-7.

44 Bergdahl IA, Schütz A, Grubb A. Application of liquid chromatography - inductively coupled plasma mass spectrometry to the study of protein-bound lead in human erythrocytes. Fournal of Analysis of Atomic Spectrometry erythrocytes. Foun

45 Raghavan SRV, Culver BD, Gonick HC. Erythrocyte lead-binding protein after occupational exposure. I Relationship to lead toxicity. Environ Res 1980;22: $264-70$

46 Lolin Y, O'Gorman P. An intra-erythrocytic low molecular weight lead-binding protein in acute and chronic lead exposure and its possible protective role in lead toxicity. Ann Clin Biochem 1988;25:688-97. 